\title{
Carotene and provitamin A content of vegetables sold in Viçosa, MG, Brazil, during spring and winter
}

\author{
Pollyanna Costa Cardoso ${ }^{1 *}$, Ceres Mattos Della Lucia ${ }^{2}$, Paulo César Stringheta ${ }^{3}$, \\ José Benício Paes Chaves ${ }^{3}$, Helena Maria Pinheiro-Sant'Ana ${ }^{4}$
}

\begin{abstract}
${ }^{1}$ Course of Nutrition, Federal University of Espírito Santo, ${ }^{2}$ Course of Nutrition, Vila Velha University Center/ES, ${ }^{3}$ Department of Food Technology, Federal University of Viçosa, ${ }^{4}$ Department of Nutrition and Health, Federal University of Viçosa/MG
\end{abstract}

\begin{abstract}
This study investigated the $\alpha$ - and $\beta$-carotene content and provitamin A value of four leafy vegetables sold at local and street markets in Viçosa, MG, Brazil, in the spring and winter of 2002. Carotenoids were analyzed by high-performance liquid chromatography. $\alpha$-Carotene was detected in all samples sold during spring, but was only present in a few samples of smooth and curly lettuce and kale in winter. $\beta$-Carotene was found in marked quantities in all leafy vegetables analyzed. Duncan's test ( $\alpha=5 \%)$ showed significantly higher $\alpha$-carotene content in curly lettuce and vitamin A value in large-leaved watercress in the spring. Mean $\beta$-carotene content and vitamin A value were 7544, 8751, 2584, 2792, 8193, and $5338 \mu \mathrm{g} / 100 \mathrm{~g}$ and $666,760,227,238,698$, and $460 \mu \mathrm{g}$ RAE/100 g in large-leaved and hydroponic watercress, smooth and curly lettuce, kale and spinach, respectively. All leafy vegetables analyzed represent important sources of provitamin A and supply an important part of the daily requirements of children and adults.
\end{abstract}

Uniterms: $\alpha$-Carotene. $\beta$-Carotene. Leafy vegetables/analysis. Provitamin A.

Investigou-se o conteúdo de $\alpha$ e $\beta$-caroteno e avaliou-se o valor pro-vitamínico A de quatro hortaliças folhosas comercializadas em mercados locais e feira- livre de Viçosa, MG durante a primavera e o inverno de 2002. Os carotenóides foram analisados por Cromatografia Líquida de Alta Eficiência (CLAE). O $\alpha$-caroteno foi detectado em todas as amostras analisadas na primavera, porém no inverno, somente algumas amostras de alface crespa e lisa, e couve apresentaram tal carotenóide. O $\beta$-caroteno foi encontrado, em quantidades apreciáveis, em todas as hortaliças folhosas analisadas. O teste de Duncan $(\alpha=5 \%)$ detectou que o conteúdo de $\alpha$-caroteno em alface crespa e o valor de vitamina A em agrião de folha larga foram estatisticamente superiores na primavera. Os teores médios de $\beta$-caroteno e de valor de vitamina A para agrião de folha larga e hidropônico, alface crespa e lisa, couve e espinafre foram: 7544 ; 8751; 2584; 2792; 8193; $5338 \mu \mathrm{g} / 100 \mathrm{~g}$ e 666; 760; 227; 238; 698; $460 \mu \mathrm{g}$ RAE/100g, respectivamente. Todas as hortaliças folhosas analisadas constituem importantes fontes de provitamina A e suprem grande parte das recomendações diárias de crianças e adultos.

Unitermos: $\alpha$-caroteno. $\beta$-caroteno. Hortaliças folhosas/análise. Pró-vitamina A.

\section{INTRODUCTION}

Dark green leafy vegetables are good sources of minerals and vitamins (Raju et al., 2007), and are important because they are rich in provitamin A carotenoids (Graebner et al., 2004; Zanutto, Jordão, Vannucchi, 2003). Since humans are unable to synthesize carotenoids, they exclusively depend on dietary intake as a source of these

*Correspondence: P.C. Cardoso. Curso de Nutrição, Universidade Federal do Espírito Santo, Alto Universitário, s/n, Caixa Postal 16 -Guararema, 29500000 - Alegre - ES, Brasil. E-mail: pcc@cca.ufes.br micronutrients (Barbosa-Filho et al., 2008). Carotenoids have raised continued interest because of studies demonstrating their role in the prevention of certain types of cancer, such as lung, breast, oral cavity, colon and rectal cancer (Barbosa-Filho et al., 2008; Melendez-Martinez, Vicario, Heredia, 2004; Silva, Naves, 2001; Fontana et al., 2000; Olson, 1999; Cozzi et al., 1997), their inhibitory action against gastric ulcers, their action on the immune system, and their role in the prevention of cardiovascular diseases and cataract (Stahl, Sies, 2005; Fontana et al., 2000; Olson, 1999; Pratt, 1999). 
Due to their tropical and subtropical climate, developing countries, especially Brazil, count on large sources of carotenoids (Rodriguez-Amaya, 2000), such as leafy vegetables, which are relatively inexpensive and readily available throughout the year. In view of the high cost of foods of animal origin, vegetables account for $82 \%$ of dietary vitamin A intake in developing countries (Van Den Berg et al., 2000).

Vitamin A deficiency continues to be a public health problem in various regions of Brazil and is associated with the limited intake of vitamin A-containing foods (Brasil, 2007). Strategies to combat vitamin A deficiency in developing countries are based on the consumption of foods rich in provitamin carotenoids (Zanutto, Jordão, Vannucchi, 2003; Gibson, Hotz, 2001). Intervention programs should be adopted in Brazil to prevent and/or reduce vitamin A deficiency, including nutritional education and food fortification for risk populations (Milagres, Nunes, Pinheiro-Sant'Ana, 2007).

However, numerous factors may interfere with the carotenoid content of foods, such as maturation stage (Rodriguez-Amaya, 2000), differences between plant varieties (Olson, 1999), climate conditions, soil type, effect of agrochemicals, differences in distribution among distinct parts of the plant, cultivation conditions, presence of damage to the plant structure, exposure to light, and storage and processing conditions (Amaya-Farfan, 1999). One important factor affecting the carotenoid content of foods is the commercialization condition of vegetables by establishments such as street and local markets. The Brazilian system of distribution of fruits and vegetables has been characterized over the last decades by a shift in importance from traditional suppliers such as street markets to supermarkets, greengrocers and grocery stores (Poletto, Carvalho, Salay, 1996; Rezende, Castro, Starling, 1995). This change is explained by consumer preference in terms of the localization of the establishment, availability of parking, price, appearance of the clean product, personal safety, possibility of rapid purchase, and a variety of products other than fruits and vegetables (Fonseca, Silva, Salay, 1999).

Studies investigating the provitamin A carotenoid content of vegetables during the four seasons of the year are controversial. According to Azevedo and Rodriguez-Amaya (2005), carotenoid content is affected by climate alterations, with exposure to sunlight and higher temperatures increasing the biosynthesis of carotenoids but, at the same time, inducing photodegradation, thus reducing their levels in plants. Studies investigating the carotenoid content of leafy vegetables are important to provide better information to consumers and healthcare workers since they estimate the daily intake of carotenoid-rich foods and their relationship with health and disease (Raju et al., 2007).

Therefore, the objective of the present study was to evaluate the $\alpha$ - and $\beta$-carotene content and provitamin A activity of leafy vegetables sold at local and street markets in Viçosa, Minas Gerais, Brazil, in the spring and winter of 2002 .

\section{MATERIAL AND METHODS}

\section{Sample collection and preparation}

Samples of the following four types of leafy vegetables were collected on three different days at four sites of sale (three local markets and one street market) during spring and winter: large-leaved and hydroponic watercress (Nasturtium officinale), curly and smooth lettuce (Lactuca sativa), kale (Brassica oleracea var. acephala), and spinach (Spinacea oleracea).

The markets were chosen based on observations made during previous visits to select those that sell the same vegetables grown at similar locations and under similar conditions. At the street market, stands presenting similar conditions, cultivation sites and commercialization were selected. The leafy vegetables sold at the street market were produced in the rural area of Viçosa by the marketers themselves, whereas the vegetables sold at the local markets were produced in neighboring regions such as Coimbra, Porto Firme and Paraíso (rural area of Viçosa), or were from the Central Supply Market (CEASA) of Belo Horizonte. At the street market, the leafy vegetables were sold in the same day they were harvested at stands exposed to the sun or covered with a plastic sheet. At the local markets, the vegetables were exposed to ambient temperature for $24 \mathrm{~h}$ or longer.

After collection, the samples were stored in a refrigerator at $5-10{ }^{\circ} \mathrm{C}$ until the time of analysis. About 30 $\mathrm{g}$ of each vegetable was collected, stored in transparent plastic bags, covered with aluminum foil, identified and sent to the laboratory. The vegetables were washed under running water, dried on paper towels, cut into small pieces, and homogenized for subsequent trituration. Extraction of carotenoids from the vegetables was performed on the same day of collection.

\section{Reagents and equipment}

The following analytical grade reagents were used for preparation of the samples: acetone, petroleum ether, anhydrous sodium sulfate, ethyl ether, Hyflosupercel, and magnesium oxide. 
The samples were filtered using Whatmann No. 40 ash-free filter paper (England), 3-mL sterile disposable syringes (Arrow Medical Supply Co. Ltd., Korea), and $0.45-\mu \mathrm{m}$ Millex-HV filter units made of polyethylene (Millipore, Brazil).

The mobile phase consisted of HPLC grade methanol and acetonitrile (OmniSolv, EM Science, USA) and ethyl acetate (Merck, Brazil).

A bench grinder (MA 102, Marconi), vacuum pump, and rotary evaporator (model 344.1, Quimis) were used for sample preparation. The mobile phase was degasified in an ultrasonic bath (T-14, Odontobrás).

For high-performance liquid chromatography (HPLC), a Shimadzu LC chromatograph equipped with a high-pressure pump, manual injector with a $50-\mu \mathrm{L}$ size loop, Lichrospher 100 column RP-18 (Merck; $5 \mu \mathrm{m}, 250$ $\mathrm{mm}$ long $\mathrm{x} 4 \mathrm{~mm}$ internal diameter), and UV-visible spectrophotometer detector (model SPD 10 AV, Shimadzu) was used.

\section{Extraction of carotenoids}

Carotenoids were extracted according to the method described by Rodriguez et al. (1976), with some modifications. About $5 \mathrm{~g}$ of each sample was triturated with cold acetone in a bench grinder and vacuum filtered through a Büchner funnel containing ash-free filter paper. The extract was transferred in a stepwise fashion to a separation funnel containing cold petroleum ether and then washed in distilled water until complete removal of the acetone. Anhydrous sodium sulfate was added to remove any residual water. The extract was concentrated in a rotary evaporator at $35-37^{\circ} \mathrm{C}$. The pigments were stored in amber glass flasks sealed with aluminum lids and frozen at $5{ }^{\circ} \mathrm{C}$ until the time of carotenoid analysis.

All chemical analyses were performed in the dark, with care taken to protect the pigments from light and oxygen by using amber glassware or aluminum foil to wrap the glassware.

\section{Chromatographic analysis}

The presence of carotenoids in the samples was analyzed by HPLC. About 1 to $2 \mathrm{~mL}$ of the extract stored in petroleum ether was evaporated under a nitrogen flow and resuspended in acetone. The extracts were then filtered through a $0.45-\mu \mathrm{m}$ filter unit and 20 to $30 \mu \mathrm{L}$ of the sample was injected into the chromatographic column.

The chromatographic conditions used were those described by Pinheiro-Sant'Ana et al. (1998), with some modifications: Shimadzu chromatograph; mobile phase consisting of methanol:acetonitrile:ethyl acetate (80:10:10); flow rate of the mobile phase: $2.0 \mathrm{~mL} / \mathrm{min}$; run time: $13 \mathrm{~min}$.

\section{Preparation of the $\alpha$ - and $\beta$-carotene standards}

$\alpha$-Carotene and $\beta$-carotene extracted from carrots by open-column chromatography according to PinheiroSant'Ana et al. (1998) were used as vitamin standards. Briefly, about $20 \mathrm{~g}$ of carrots was triturated with acetone and petroleum ether was added. A magnesium oxide:Hyflosupercel $(1: 2)$ column was used, with the mobile phase consisting of $2 \%$ ethyl ether in petroleum ether. The carotenoids obtained were identified using the following parameters: order of elution of the fractions from the column; color of the eluted pigments; HPLC retention time, and absorption spectra of the carotenoids of interest. The $\alpha$ - and $\beta$-carotene solutions were quantified by spectrophotometry based on maximum absorbance according to Beer's law. The absorption coefficients ( 2800 and 2592) and wavelengths of maximum absorption (444 and $449 \mathrm{~nm}$ ) of $\alpha$ - and $\beta$-carotene, respectively, were obtained according to Rodriguez-Amaya (1989). External standard curves were used for the quantification of $\alpha$ - and $\beta$-carotene in the samples.

\section{Calculation of vitamin $A$ value}

Vitamin A value is expressed as retinol activity equivalent (RAE) per $100 \mathrm{~g}$ sample according to the conversion factors for vitamin A value established by the Institute of Medicine (IOM, 2001). The IOM defines that 1 RAE corresponds to $1 \mu \mathrm{g}$ retinol or $12 \mu \mathrm{g} \beta$-carotene or $24 \mu \mathrm{g}$ of other provitamin carotenoids.

\section{Experimental design}

A completely randomized design in a factorial scheme consisting of four sampling sites (4 levels), two seasons of the year (2 levels) and three replicates for each vegetable was used. Statistical analysis was performed using the SAS program (Statistical Analysis System), version 9.1, licensed by Universidade Federal de Viçosa. Carotenoid content was analyzed by analysis of variance (ANOVA) $(\alpha=5 \%)$ to determine significant differences between sampling sites, seasons of the year and the interaction between sampling site and season of the year. Duncan's multiple range test $(\alpha=5 \%)$ was used to analyze differences in mean carotenoid content between treatments that showed significant differences by ANOVA. 


\section{RESULTS AND DISCUSSION}

\section{Qualitative analysis of $\alpha$ - and $\beta$-carotene in vegetables}

Figure 1 shows typical chromatograms obtained for samples of the vegetables studied.

$\alpha$-Carotene was found in the four types of leafy vegetables analyzed, but was not detected in some samples during winter. According to Mercadante and Rodriguez-Amaya (1991), when detected, $\alpha$-carotene is present in small amounts in leafy vegetables. AbdelKader (1991), Heinonen et al. (1989) and Bureau and Bushway (1986) detected $\alpha$-carotene in lettuce samples but not in spinach. Godoy and Rodriguez-Amaya (1998) found no $\alpha$-carotene in watercress. In a study analyzing 11 leafy vegetables, $\alpha$-carotene was only detected in kale, amaranth, parsley and taro (Mercadante, Rodriguez-Amaya, 2001). In a literature review of data regarding sources of carotenoids published by Barbosa-Filho et al. (2008), $\alpha$ - and $\beta$-carotene were found in kale, lettuce and spinach.

$\beta$-Carotene was detected in all leafy vegetables analyzed. From a nutritional point of view, $\beta$-carotene is considered to be the main provitamin A (Niizu, RodriguezAmaya, 2005; Moreira et al., 2005; Campos et al., 2003; Almeida-Muradian, Penteado, 2003; Rodriguez-Amaya, 1996).

\section{Quantitative analysis of $\alpha$ - and $\beta$-carotene in vegetables}

The $\alpha$-carotene content of the leafy vegetable samples analyzed is shown in Table I. $\alpha$-Carotene was detected in all samples analyzed during spring. However, in the winter only a few samples of curly and smooth lettuce and kale contained this carotenoid. A significant difference $(\mathrm{p} \leq$ $0.05)$ in $\alpha$-carotene content between the two seasons was only observed for curly lettuce, with $\alpha$-carotene content being higher in the spring.

In the spring, mean $\alpha$-carotene content was 857 , $735,198,191,448$ and $297 \mu \mathrm{g} / 100 \mathrm{~g}$ in large-leaved and hydroponic watercress, curly and smooth lettuce, kale and spinach, respectively. In the winter, mean $\alpha$-carotene content was $58 \mu \mathrm{g} / 100 \mathrm{~g}$ in curly lettuce, $93 \mu \mathrm{g} / 100 \mathrm{~g}$ in smooth lettuce, and $182 \mu \mathrm{g} / 100 \mathrm{~g}$ in kale. Thus, largeleaved watercress presented the highest $\alpha$-carotene content in the spring, whereas curly lettuce presented the lowest amount in the winter.

Analysis of studies in the literature investigating the carotenoid composition of leafy vegetables revealed different results regarding the presence of $\alpha$-carotene in the same vegetable, even when the same analytical method was used (Mercadante, Rodriguez-Amaya, 2001). These results can be explained by differences between varieties and cultivars, the effect of climate and soil, and the presence of minor carotenoids in leaves.
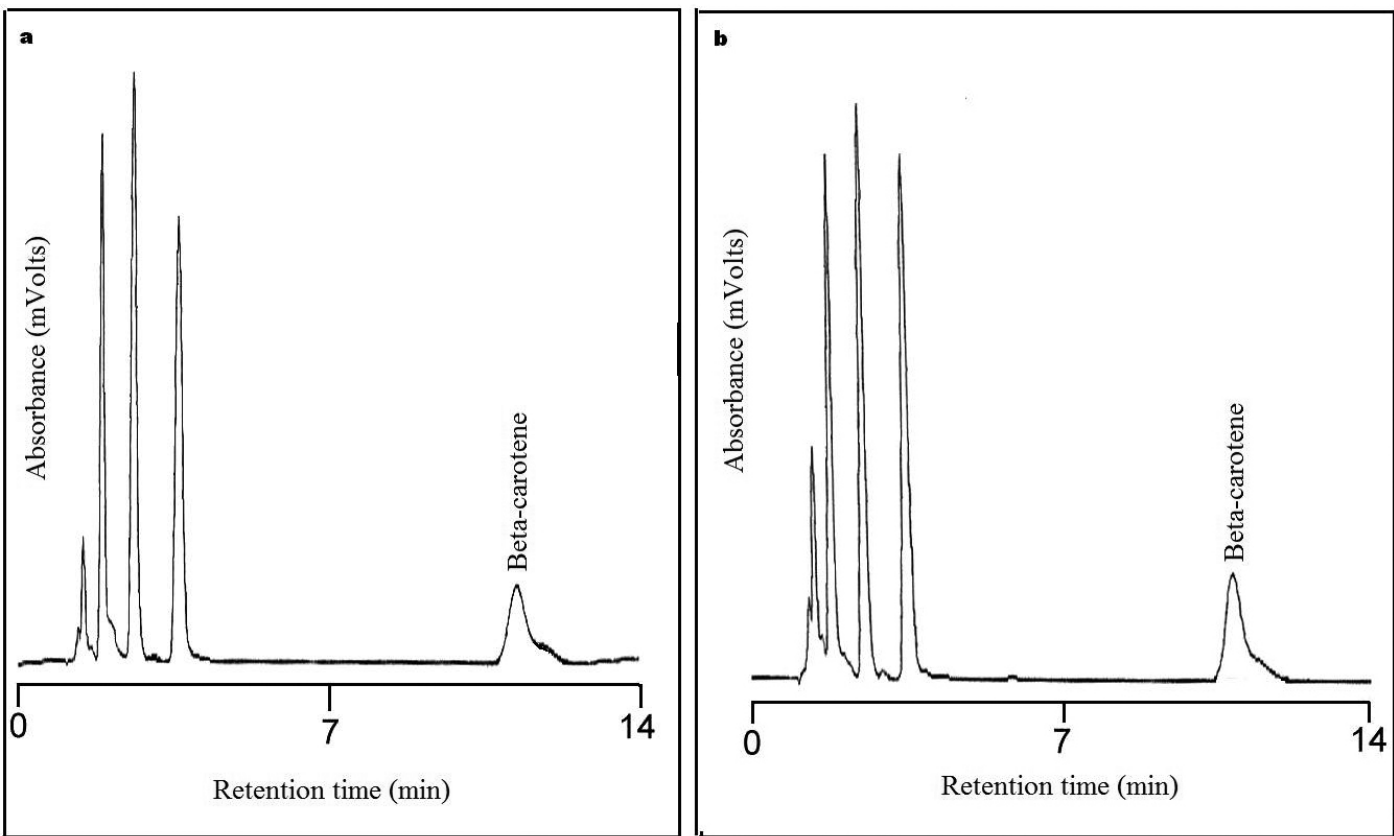

FIGURE 1. HPLC analysis of carotenes in samples of large-leaved watercress (a) and smooth lettuce (b). Chromatographic conditions: mobile phase, methanol:acetonitrile:ethyl acetate (80:10:10); RP 18 column; detection at $450 \mathrm{~nm}$; flow rate: $2 \mathrm{~mL} / \mathrm{min}$; injection volume: $30 \mu \mathrm{L}$. 
TABLE I - Mean $\alpha$-carotene content ( $\mu \mathrm{g} / 100 \mathrm{~g}$ ) of leafy vegetables sold in Viçosa, MG, in the spring and winter of 2002 (values are expressed on a wet weight basis)

\begin{tabular}{|c|c|c|c|c|c|c|c|c|}
\hline \multirow{3}{*}{ Leafy vegetable } & \multicolumn{4}{|c|}{ Spring } & \multicolumn{4}{|c|}{ Winter } \\
\hline & \multicolumn{3}{|c|}{ Local markets } & \multirow{2}{*}{ Street market } & \multicolumn{3}{|c|}{ Local markets } & \multirow{2}{*}{$\begin{array}{l}\text { Street } \\
\text { marke }\end{array}$} \\
\hline & 1 & 2 & 3 & & 1 & 2 & 3 & \\
\hline $\begin{array}{l}\text { Hydroponic } \\
\text { watercress }\end{array}$ & $820.44 a$ & $884.64 \mathrm{a}$ & $500.28 \mathrm{a}$ & --- & --- & --- & --- & --- \\
\hline Smooth lettuce & $155.52 \mathrm{a}$ & $206.04 \mathrm{a}$ & $235.08 \mathrm{a}$ & $165.60 \mathrm{a}$ & $*$ & $54.24 \mathrm{a}$ & $132.36 \mathrm{a}$ & $*$ \\
\hline Kale & $441.48 \mathrm{a}$ & $342.00 \mathrm{a}$ & $448.80 \mathrm{a}$ & $561.12 \mathrm{a}$ & $*$ & $*$ & $182.28 \mathrm{a}$ & $*$ \\
\hline Spinach & $289.80 \mathrm{a}$ & $299.28 \mathrm{a}$ & $305.04 \mathrm{a}$ & $294.60 \mathrm{a}$ & --- & $*$ & $*$ & $*$ \\
\hline
\end{tabular}

(---) Vegetable not sold at the establishment.

(*) Not detected.

Means within the same row followed by the same letter are not significantly different by ANOVA $(p>0.05)$.

Means within the same row followed by different letters differ significantly by the Duncan test $(\mathrm{p} \leq 0.05)$.

Table II shows the $\beta$-carotene content of the leafy vegetable samples analyzed. The main carotenoids of green leaves are lutein, corresponding to $45 \%$ of all carotenoids, and $\beta$-carotene, corresponding to $25 \%$, although a marked variation in their absolute concentration has been reported (Kimura, Rodriguez-Amaya, 2003; Almeida Muradian, Vanderlinde, Sasaki, 2000; Rodriguez-Amaya, 1993).

In the spring, mean $\beta$-carotene content was 8631 , $8751,2602,2857,8424$ and $5726 \mu \mathrm{g} / 100 \mathrm{~g}$ in large-leaved and hydroponic watercress, curly and smooth lettuce, kale and spinach, respectively. In the winter, mean $\beta$-carotene content was $6095 \mu \mathrm{g} / 100 \mathrm{~g}$ in large- leaved watercress, $2566 \mu \mathrm{g} / 100 \mathrm{~g}$ in curly lettuce, $2727 \mu \mathrm{g} / 100 \mathrm{~g}$ in smooth lettuce, $7962 \mu \mathrm{g} / 100 \mathrm{~g}$ in kale, and $4821 \mu \mathrm{g} / 100 \mathrm{~g}$ in spi- nach. Thus, large-leaved and hydroponic watercress contained the highest $\beta$-carotene levels in the spring, whereas in the winter kale was the leafy vegetable that presented the highest content of this carotene.

No significant difference $(p>0.05)$ in $\beta$-carotene content was observed between vegetables sold at local and street markets of Viçosa during spring and winter (Table II).

Studies have shown that in European countries, where the climate is temperate and marked climate variation occurs, the carotenoid content of vegetables varies significantly over the year (Granado et al., 1992; Heinonen et al., 1989). Campos et al. (2006) found no variation in the carotene content of vegetables sold in Viçosa, MG,

TABLE II - Mean $\beta$-carotene content ( $\mu \mathrm{g} / 100 \mathrm{~g}$ ) of leafy vegetables sold in Viçosa, MG, in the spring and winter of 2002 (values are expressed on a wet weight basis)

\section{Spring}

Leafy vegetable $\quad$ Local markets

\section{Winter}

Local markets

$\begin{array}{lccc}\text { Street market } & \text { Local markets } & \text { Street market }\end{array}$

\begin{tabular}{|c|c|c|c|c|c|c|c|c|}
\hline & 1 & 2 & 3 & . & 1 & 2 & 3 & \\
\hline $\begin{array}{l}\text { Large-leaved } \\
\text { watercress }\end{array}$ & $7776.26 \mathrm{a}$ & $4515.39 a$ & $11029.80 \mathrm{a}$ & $11202.26 \mathrm{a}$ & --- & $7467.95 \mathrm{a}$ & $4946.08 \mathrm{a}$ & $5870.66 a$ \\
\hline $\begin{array}{l}\text { Hydroponic } \\
\text { watercress }\end{array}$ & $8836.61 \mathrm{a}$ & $9224.31 \mathrm{a}$ & $8190.61 \mathrm{a}$ & --- & --- & --- & --- & --- \\
\hline Curly lettuce & $1902.68 \mathrm{a}$ & $2473.35 \mathrm{a}$ & $2629.48 \mathrm{a}$ & $3403.12 \mathrm{a}$ & $2514.25 \mathrm{a}$ & $3231.27 \mathrm{a}$ & $2267.79 a$ & $2252.46 a$ \\
\hline Smooth lettuce & $2815.11 \mathrm{a}$ & $2361.86 a$ & $2672.16 \mathrm{a}$ & $3580.02 \mathrm{a}$ & $3095.08 \mathrm{a}$ & $2725.36 \mathrm{a}$ & $2984.59 a$ & $2101.06 \mathrm{a}$ \\
\hline Spinach & $5821.15 \mathrm{a}$ & $5298.37 \mathrm{a}$ & $5003.40 \mathrm{a}$ & $6779.45 \mathrm{a}$ & --- & $4876.24 \mathrm{a}$ & $4813.57 \mathrm{a}$ & $4772.11 \mathrm{a}$ \\
\hline
\end{tabular}

(---) Vegetable not sold at the establishment.

Means within the same row followed by the same letter are not significantly different by ANOVA $(p>0.05)$. 
between three seasons of the year (spring, summer and autumn), except for green peppers. However, in countries such as Brazil where differences in climate conditions are only observed between summer and winter, the carotenoid content of vegetables may vary between these two seasons.

Although statistical analysis showed no significant difference in the $\beta$-carotene content of vegetable sold during the two seasons, higher levels of this carotene were observed in all leafy vegetables sold at the street market during spring. This finding is probably due to the shorter period of storage of these vegetables since they were harvested the previous night or on the same day of distribution, the shorter transportation time (rural area of Viçosa) when compared to that of vegetables sold at the local markets (neighboring regions such as Coimbra, Porto Firme and Paraíso or even from CEASA-Belo Horizonte), and shorter time of commercialization ( 7 to $12 \mathrm{~h}$ ). At the local markets, the vegetables were stored for $24 \mathrm{~h}$ or longer, a fact resulting in the degradation of carotenes. However, in the winter the vegetables originating from the local markets presented a higher content of this carotene.

The lack of significant differences in the carotenoid content of the vegetables studied might be explained by the marked variation between replicates, sampling sites and seasons of the year. Analysis should consider the different types of commercialization of vegetables, including the location of cultivation, harvest conditions, duration and type of storage and exposure for sale, in addition to stage of maturation, varieties, effect of chemical products, and distribution in the plant (Giuntini et al., 2005; AlmeidaMuradian, Penteado, 2003; Rodriguez-Amaya, 2000; Amaya-Farfan, 1999; Olson, 1999). One or more factors may have influenced the carotene content of the samples analyzed, since this study was conducted under real con- ditions of vegetable commercialization in the absence of control for the parameters described above.

Comparison of the quantitative distribution of carotenoids in the vegetables analyzed (Figure 2) with literature data showed that the mean $\beta$-carotene content found in watercress, lettuce, kale and spinach samples was higher than that reported in other studies. Campos et al. (2003) found a $\beta$-carotene content of $4330 \mu \mathrm{g} / 100 \mathrm{~g}$ in watercress and of $1482 \mu \mathrm{g} / 100 \mathrm{~g}$ in lettuce served at commercial restaurants in Viçosa, MG. In a study conducted in Campinas, SP, Godoy and Rodriguez-Amaya (1998) observed trans- $\beta$-carotene concentrations of 2580,2500 and $2330 \mu \mathrm{g} / 100 \mathrm{~g}$ in kale, spinach and watercress, respectively. Della Lucia et al. (2008) reported a $\beta$-carotene content of kale ranging from 4856 to $7409 \mu \mathrm{g} / 100 \mathrm{~g}$, whereas Zanutto, Jordão and Vannucchi (2003) found a value of $3700 \mu \mathrm{g} / 100 \mathrm{~g}$. A $\beta$-carotene content of 2006 and $2400 \mu \mathrm{g} / 100 \mathrm{~g}$ in lettuce and spinach, respectively, has been reported by Ismail and Fun (2003). Hart and Scott (1995) found $\beta$-carotene concentrations of 1603,3397 and $4777 \mu \mathrm{g} / 100 \mathrm{~g}$ in samples of lettuce, spinach and watercress, respectively. Khachik et al. (1992) found a $\beta$-carotene content of $8900 \mu \mathrm{g} / 100 \mathrm{~g}$ in spinach. Granado et al. (1992) reported $\beta$-carotene concentrations of 172 and $3254 \mu \mathrm{g} / 100 \mathrm{~g}$ for lettuce and spinach, respectively.

\section{Provitamin A value of vegetables}

Vitamin A values showed a variation similar to that observed for $\beta$-carotene, except for samples in which $\alpha$ carotene was also detected, a fact contributing to a higher total vitamin A value in these vegetables.

As can be seen in Table III, a significant difference in vitamin A value between the two seasons was only

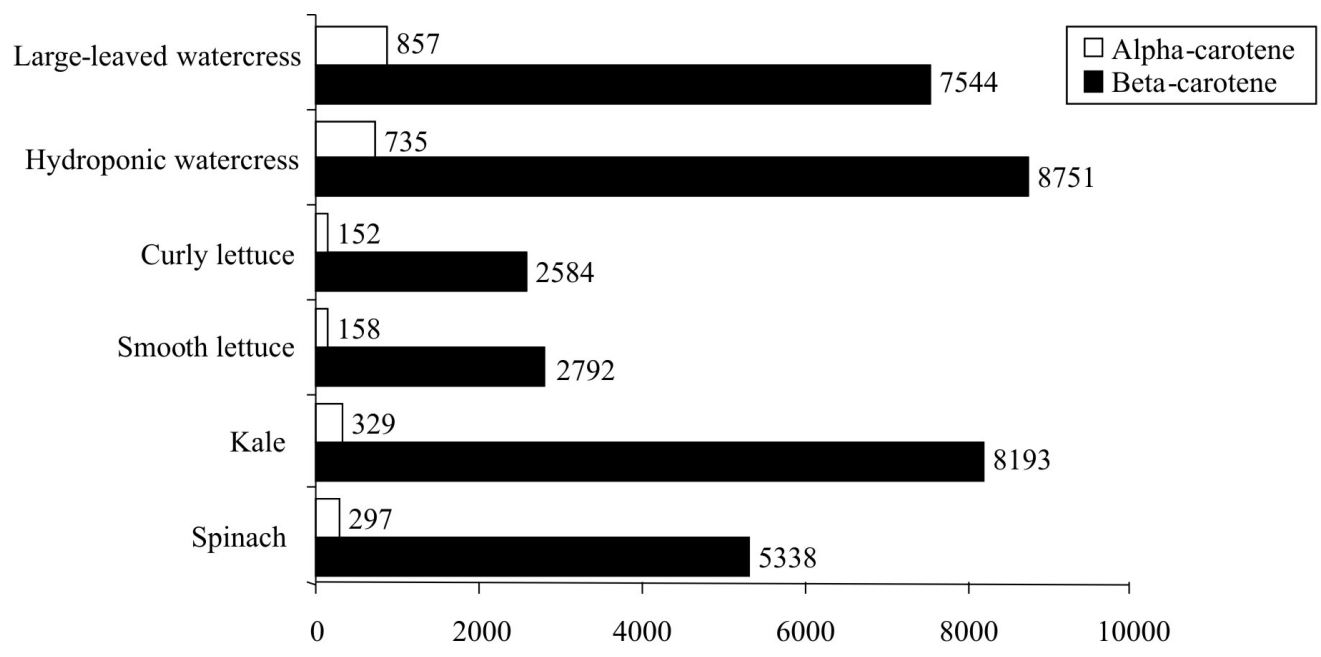

FIGURE 2 - Mean $\alpha$ - and $\beta$-carotene content ( $\mu \mathrm{g} / 100 \mathrm{~g}$ ) of leafy vegetables sold in Viçosa, MG, in the spring and winter of 2002. 
observed for large-leaved watercress $(\mathrm{p} \leq 0.05)$. Vitamin A values were significantly higher in watercress samples collected at local and street markets during spring. No significant difference in vitamin A value between treatments was observed for the other leafy vegetables. The variation in vitamin A value between samples obtained from local and street markets might be due to the biological oxidation of provitamin A carotenoids to inactive xanthophylls, a process that occurs rapidly during storage (Olson, 1991). Carotenoids can be oxidized to inactive forms both by enzymatic action during storage or by exposure to light and oxygen (Melendez-Martinez, Vicario, Heredia, 2004; Amaya-Farfan, 1999).

The highest provitamin A content was observed in kale, followed by large-leaved watercress (Figure 3 ). The mean vitamin A values found in the vegetables studied agree with data from the Brazilian Food Composition Table of the University of São Paulo (2008), which lists the vitamin $A$ and carotenoid content reported in different studies. According to this table, the vitamin A value of watercress ranges from 245 to $690 \mu \mathrm{g} / 100 \mathrm{~g}$, curly and smooth lettuce present a vitamin A value of 240 and $210 \mu \mathrm{g} / 100 \mathrm{~g}$, respectively, the vitamin A value of kale ranges from 490 to $910 \mu \mathrm{g} / 100 \mathrm{~g}$, and the vitamin A value of spinach is $450 \mu \mathrm{g} / 100 \mathrm{~g}$. Differences in quantification techniques, origins and cultivation may explain the variations in provitamin A content (Almeida-Muradian, Penteado, 2003).

Vitamin A values were used to calculate the nutritional adequacy of consumption of one portion of the vegetables by children and adults (Table IV). Mean vitamin A values found in vegetables sold at local and street markets during the two seasons were used to

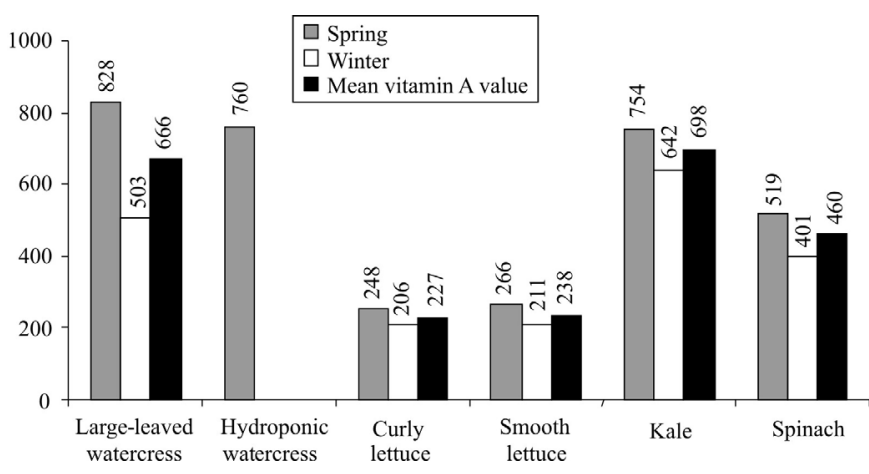

FIGURE 3 - Mean vitamin A values ( $\mu \mathrm{g}$ RAE/100 g) of leafy vegetables sold in Viçosa, MG, in the spring and winter of 2002.

evaluate this adequacy (Figure 3). Consumption of one portion of large-leaved watercress corresponds to half the recommended intake of vitamin A per day for children and to practically one-fourth of the recommended intake for male adults. In contrast, consumption of one portion of kale corresponds to $52 \%$ and $23 \%$ of the daily requirements of a child and a male adult, respectively. The consumption of two and four portions of spinach would meet the daily requirements of a child and a male adult, respectively. The other leafy vegetables (curly and smooth lettuce and hydroponic watercress), in this order, play an important role in meeting daily vitamin A requirements (Table IV). Since the leafy vegetables analyzed meet an important part of the daily vitamin A requirements of the population, consumption of these vegetables may effectively reduce vitamin A deficiencies. These vegetables are easily cultivated and accessible to the population due to their low cost compared to products of animal origin.

TABLE III - Mean value of vitamin A ( $\mu \mathrm{g}$ RAE/100 g) originating from $\alpha$ - and $\beta$-carotene in the leafy vegetables analyzed in the spring and winter of 2002 (values are expressed on a wet weight basis)

\begin{tabular}{lcccc}
\hline \multirow{2}{*}{ Leafy vegetable } & \multicolumn{2}{c}{ Spring } & \multicolumn{2}{c}{ Winter } \\
& Local markets & Street market & Local markets & Street market \\
\hline Large-leaved watercress* & $681.53 \mathrm{a}$ & $975.16 \mathrm{a}$ & $517.25 \mathrm{~b}$ & $489.22 \mathrm{~b}$ \\
Hydroponic watercress** & $759.84 \mathrm{a}$ & --- & --- & --- \\
Curly lettuce** & $201.98 \mathrm{a}$ & $294.52 \mathrm{a}$ & $225.01 \mathrm{a}$ & $187.71 \mathrm{a}$ \\
Smooth lettuce** & $226.32 \mathrm{a}$ & $305.24 \mathrm{a}$ & $248.47 \mathrm{a}$ & $175.09 \mathrm{a}$ \\
Kale** & $687.06 \mathrm{a}$ & $821.52 \mathrm{a}$ & $693.39 \mathrm{a}$ & $596.64 \mathrm{a}$ \\
Spinach** & $460.28 \mathrm{a}$ & $577.23 \mathrm{a}$ & $403.74 \mathrm{a}$ & $397.68 \mathrm{a}$ \\
\hline
\end{tabular}

(---) Vegetable not sold at the establishment.

*Means within the same row followed by the same letter are not significantly different by the Duncan test ( $\mathrm{p}>0.05)$.

**Means within the same row followed by the same letter are not significantly different by ANOVA $(p>0.05)$. 
TABLE IV - Adequacy of the value of vitamin A originating from $\alpha$ - and $\beta$-carotene of leafy vegetables sold in Viçosa, MG, in the spring and winter of 2002

\begin{tabular}{lcccc}
\hline Leafy vegetable & Portion $^{1}(\mathrm{~g})$ & $\begin{array}{c}\text { Vitamin A value }^{2} \\
(\mu \mathrm{g} \text { RAE/portion })\end{array}$ & $\begin{array}{c}\text { Adequacy in children } \\
(\%)\end{array}$ & \begin{tabular}{c} 
Adequacy in $_{\operatorname{men}^{4}(\%)}$ \\
\hline Large-leaved watercress
\end{tabular} \\
Hydroponic watercress & 30 & 199.8 & 50.0 & 22.2 \\
Curly lettuce & 40 & 228.0 & 57.0 & 25.3 \\
Smooth lettuce & 40 & 90.8 & 22.7 & 10.1 \\
Kale & 30 & 95.2 & 23.8 & 10.6 \\
Spinach & 50 & 209.4 & 52.4 & 23.3 \\
\hline
\end{tabular}

${ }^{1}$ Corresponding to the following home measures: watercress: 6 medium branches; lettuce: 4 medium leaves; kale: 3 full soup spoons; spinach: 2 full soup spoons (Pinheiro et al., 2005).

${ }^{2}$ Mean of four sampling sites during the two seasons (spring and winter).

${ }^{3}$ DRI (2000) for children aged 4 to 8 years: $400 \mu \mathrm{g} /$ day.

${ }^{4}$ DRI (2000) for a male adult aged 14 to 70 years: $900 \mu \mathrm{g} /$ day.

\section{CONCLUSIONS}

$\alpha$-Carotene and $\beta$-carotene were found in all leafy vegetables analyzed. However, $\alpha$-carotene was not detected in some of the samples, whereas $\beta$-carotene was present in marked amounts in all leafy vegetables analyzed. A significant difference in $\alpha$-carotene content between the two seasons was only observed for curly lettuce, with $\alpha$ carotene content being higher in the spring. Large-leaved watercress sold at local and street markets during spring presented a significantly higher vitamin A value than watercress sold during winter. The leafy vegetables sold in Viçosa, MG, were characterized by a high provitamin A content, occupying a special position when compared to those analyzed in other regions of Brazil and of the world. The vegetables studied may supply an important part of the daily vitamin A requirements of children and adults by being available to the population practically throughout the year at accessible prices.

\section{ACKNOWLEDGEMENT}

We thank Conselho Nacional de Desenvolvimento Científico e Tecnológico (CNPq) for financial support.

\section{REFERENCES}

ABDEL-KADER, Z. M. Determination of carotenoids in foods by high-performance liquid chromatography. Die Nahrung, v.35, n.7, p.689-693, 1991.
ALMEIDA MURADIAN, L. B.; VANDERLINDE, D. W.; SASAKI, R. Provitamin A activity of raw and cooked Brazilian leaves. Ciênc. Tecnol. Aliment., v.20, n.2, p.151153, 2000.

ALMEIDA-MURADIAN, L. B.; PENTEADO, M. V. C. Carotenóides. In: PENTEADO, M. V. C. Vitaminas: aspectos nutricionais, bioquímicos, clínicos e analíticos. São Paulo: Ed. Manole, 2003. p.3-52.

AMAYA-FARFAN, J. Panorama de la investigación sobre carotenoides en el Brasil. Perspectiva y necesidades. Arch. Latinoam. Nutr., v.49, n.1-S, p.92-94, 1999.

AZEVEDO, C. H. de; RODRIGUEZ-AMAYA, D. B. Carotenoid composition of kale as influenced by maturity, season and minimal processing. J. Sci. Food Agric., v. 85, n.4, p.591-597, 2005.

BARBOSA-FILHO, J. M.; ALENCAR, A. A.; NUNES, X. P.; TOMAZ, A. C. A.; SENA-FILHO, J. G.; ATHAYDEFILHO, P. F.; SILVA, M. S.; SOUZA, M. F. V.; DACUNHA, E. V. L. Sources of alpha-, beta-, gamma-, deltaand epsilon-carotenes: a twentieth century review. Rev. Bras. Farmacogn., v.18, n.1, p.135-154, 2008.

BRASIL. Ministério da Saúde. Departamento de Atenção Básica. Alimentação e Nutrição. Vitamina A. Disponível $\mathrm{em}<\mathrm{http}: / / \mathrm{dtr} 2004$.saude.gov.br/nutricao/vita.php $>$. Acesso em: 16 jun. 2007. 
BUREAU, J. L.; BUSHWAY, R. J. HPLC determination of carotenoids in fruits and vegetables in the United States. $J$. Food Sci., v.51, n.1, p.128-130, 1986.

CAMPOS, F. M.; PINHEIRO-SANT'ANA, H. M.; SOUZA, P.M. de; STRINGHETA, P. C.; CHAVES, J. B. P. Próvitaminas A em hortaliças comercializadas no mercado formal e informal de Viçosa (MG), em três estações do ano. Ciên. Tecnol. Alim., Campinas, v.26, n.1, p.33-40, 2006.

CAMPOS, F. M.; PINHEIRO-SANT'ANA, H. M.; STRINGHETA, P. C.; CHAVES, J. B. P. Teores de betacaroteno em vegetais folhosos preparados em restaurantes comerciais de Viçosa-MG. Braz. J. Food Technol., v.6, n.2, p.163-169, 2003.

COZZI, R.; RICORDY, R.; AGLITTI, T.; GATTA, V.; PERTICONE, P.; SALVIA, R. de. Ascorbic acid and $\beta$-carotene as modulators of oxidative damage. Carcinogenesis, v.18, n.1, p.223-228, 1997.

DELLA LUCIA, C. M.; CAMPOS, F. M.; MATA, G. M. S. C.; PINHEIRO-SANT'ANA, H. M.. Controle de perdas de carotenóides em hortaliças preparadas em unidade de alimentação e nutrição hospitalar. Ciênc. Saúde Colet., v.13, n.5, p.1627-1636, 2008.

FONSECA, M. da C. P. da; SILVA, M. A. A. P. da; SALAY, E. Atitudes dos consumidores com relação à compra de hortifrutícolas em hipermercados e feiras livres na cidade de Campinas - SP. Cad. Ciênc. Tecnol., Brasília, v.16, n.1, p.87-113, 1999.

FONTANA, J. D.; MENDES, S. V.; PERSIKE, D. S.; PERACETTA, L. F.; PASSOS, M. Carotenoídes. Cores atraentes e ação biológica. Biotecnol. Ciênc. Des., v.2, n.13, p.40-45, 2000.

FOOD AND NUTRITION BOARD. Institute of Medicine. National Academy of Sciences. Dietary Reference Intakes for vitamin A, vitamin $K$, arsenic, boron, chromium, copper, iodine, iron, manganese, molybdenum, nickel, silicon, vanadium and zinc. Washington, National Academy Press, 2000. Disponível em <http://www.nap.edu>. Acesso em: 18 jun. 2007.

GIBSON, R.S., HOTZ, C. Dietary diversification/modification strategies to enhance micronutrient content and bioavailability of diets in developing countries. British Journal of Nutrition, v.85, n.2, p.S159-S166, 2001.
GIUNTINI, D.; GRAZIANI, G; LERCARI, B.; FOGLIANO, V.; SOLDATINI, G.F.; RANIERI, A. Changes in carotenoid and ascorbic acid contents in fruits of different tomato genotypes related to the depletion of UV-B radiation. $J$. Agric. Food Chem., v.53, n.8, p.3174-3181, 2005.

GODOY, H. T.; RODRIGUEZ-AMAYA, D. Occurrence of cis isomers of provitamins A in Brazilian vegetables. J. Agric. Food Chem., v.46, n.8, p.3081-3086, 1998.

GRAEBNER, I. T.; SIQUEIRA, E. M. A.; ARRUDA, S. F.; SOUZA, E. M. T. de. Carotenoids from native Brazilian dark-green vegetables are bioavailable: a study in rats. Nutr. Res., v.24, n.8, p.671-679, 2004.

GRANADO, F.; OLMEDILLA, B.; BLANCO, I.; ROJASHIDALGO, E. Carotenoid composition in raw and cooked Spanish vegetables. J. Agric. Food Chem., v.40, n.11, p.2135-2140, 1992.

HART, D. J.; SCOTT, K. J. Development and evaluation of HPLC method for the analysis of carotenoids in foods, and the measurement of the carotenoid content of vegetables and fruits commonly consumed in the UK. Food Chem., v.54, n.11, p.101-111, 1995.

HEINONEN, M. I.; OLLIAINEN, V.; LINKOLA, E. K.; VARO, P. T.; KOIVISTOINEN, P.E. Carotenoids in finish foods: vegetables, fruits, and berries. J. Agric. Food Chem., v.37, n.3, p.655-659, 1989.

INSTITUTE OF MEDICINE (IOM-U.S.). Food and Nutrition Board. Standing Committee on the Scientific Evaluation of Dietary Reference Intakes. Dietary reference intakes for vitamin a, vitamin $\mathrm{k}$, arsenic, boron, chromium, copper, iodine, iron, manganese, molybdenum, nickel, silicon, vanadium and zinc. Washington: National Academy Press, 2001. 797p.

ISMAIL, A.; FUN, C. S. Determination of vitamin C, $\beta$-carotene and riboflavin contents in five green vegetables organically and conventionally grown. Mal. J. Nutr., v.9, n.1, p.31-39, 2003.

KHACHIK, F; GOLI, M. B.; BEECHER, G. R.; HOLDEN, J.; LUSBY, W. R.; TENORIO, M. D.; BARRERA, M. R. Effect of food preparation on qualitative and quantitative distribution of major carotenoid constituents of tomatoes and several green vegetables. J. Agric. Food Chem., v. 40, n.3, p.390-398, 1992. 
KIMURA, M.; RODRIGUEZ-AMAYA, D. B. Carotenoid composition of hydroponic leafy vegetables. J. Agric. Food Chem., v.51, n.9, p.2603-2607, 2003.

MELENDEZ-MARTINEZ, A. J.; VICARIO, I. M.; HEREDIA, F. J. Importancia nutricional de los pigmentos carotenoides. Arch. Latinoam. Nutr., v.54, n.2, p.149-155, 2004.

MERCADANTE, A. Z.; RODRIGUEZ-AMAYA, D. B. Carotenoid composition of a leafy vegetable in relation to some agricultural variables. J. Agric. Food Chem., v.39, n.6, p.1094-1097, 1991.

MERCADANTE, A. Z.; RODRIGUEZ-AMAYA, D. Confirmação da identidade da $\alpha$-criptoxantina e incidência de carotenóides minoritários provitamínicos A em verduras folhosas verdes. Ciênc. Tecnol. Aliment., v.21, n.2, p.216222, 2001

MILAGRES, R. C. R. M.; NUNES, L. C.; PINHEIROSANT'ANA, H. M. A deficiência de vitamina A em crianças no Brasil e no mundo. Ciênc. Saúde Colet., v.12, n.5, p.1253-1266, 2007.

MOREIRA, A. P. B.; PINHEIRO-SANT’ANA, H. M.; SOUZA, S. L. de; ALENCAR, E. R. de. Atividade provitamínica A de hortaliças comercializadas no mercado formal e informal de Viçosa, MG. Rev. CERES, v.55, n.300, p.177-189, 2005.

NIIZU, P. Y.; RODRIGUEZ-AMAYA, D. B. New data on the carotenoid composition of raw salad vegetables. J. Food Compos. Anal., v.18, n.8, p.739-749, 2005.

OLSON, J. A. Carotenoids. In: SHILS, M. E.; OLSON, J. A.; SHIKE, M; ROSS, A. C. Modern Nutrition in Health and Disease. 9 ed. Baltimore: Wiliams \& Wilkins, 1999. p.525-541.

OLSON, J. A. In: MACHLIN, L. J. Handbook of Vitamins. 2. ed. New York: Marcel Dekker, 1991. p.1-57.

PINHEIRO, A. B. V.; LACERDA, E. M. A.; BENZECRY, E. H.; GOMES, M. C. S.; COSTA, V. M. Tabela para avaliação de consumo alimentar em medidas caseiras. 5.ed. São Paulo: Ed. Atheneu, 2005. 131p.

PINHEIRO-SANT'ANA, H. M.; STRINGHETA, P. C.; BRANDÃO, S. C. C.; AZEREDO, R. M. C. Carotenoid retention and vitamin A value in carrot (Daucus carota L.) prepared by food service. Food Chem., v.61, n.1-2, p.145151,1998 .
POLETTO, A. C. P.; CARVALHO, J. F.; SALAY, E. Destino dos produtos hortifrutícolas comercializados na Ceasa/ Campinas. Rev. Polít. Agríc., Brasília, v.5, n.4, p.12-15, 1996.

PRATT, S. Dietary prevention of age-related macular degeneration. J. Am. Optom. Assoc., v.70, n.1, p.39-47, 1999.

RAJU, M.; VARAKUMAR, S.; LAKSHMINARAYANA, R.; KRISHNAKANTHA, T. P.; BASKARAN, V. Carotenoid composition and vitamin A activity of medicinally important green leafy vegetables. Food Chem., v.101, n.4, p.1598-1605, 2007.

REZENDE, J. B.; CASTRO, A. R.; STARLING, M. B. L. Os problemas da comercialização de hortigranjeiros na região metropolitana de Belo Horizonte. Conjunt. Aliment., v.7, n.1, p.24-38, 1995.

RODRIGUEZ, D. B.; RAYMUNDO, L. C.; LEE, T.; SIMPSON, K. L.; CHICHESTER, C. O. Carotenoid pigment changes in ripening Momordica charantia fruits. Ann. Bot., v.40, n.3, p.615-624, 1976.

RODRIGUEZ-AMAYA, D. B. Assessment of the provitamin A contents of foods - The brazilian experience. J. Food Compos. Anal., v.9, n.3, p.196-230, 1996.

RODRIGUEZ-AMAYA, D. B. Critical review of provitamin A determination in plant foods. Journal of Micronutrients Analysis(verificar título, não há registro no ISSN), Barking, v.5, número?, p.191-225, 1989.

RODRIGUEZ-AMAYA, D. B. Nature and distribution of carotenoids in foods. In: CHARALAMBOUS, F. ed. Shelf life offoods and beverages - chemical, biological, physical and nutritional aspects. Amsterdam: Elsevier Science, 1993. p.547-589.

RODRIGUEZ-AMAYA, D. B. Some considerations in generating carotenoid data for food composition tables. $J$. Food Composit. Anal., v.13, n.4, p.641-647, 2000.

SILVA, C. R. M.; NAVES, M. M. V. Suplementação de Vitaminas na Prevenção de Câncer. Rev. Nutr., v.14, n.2, p.135-143, 2001.

STAHL, W; SIES, H. Bioactivity and protective effects of natural carotenoids. Biochim. Biophys. Acta, v.1740, n.2, p.101-107, 2005. 
TBCA-USP 5.0. Tabela Brasileira de Composição dos Alimentos. Departamento de Alimentos e Nutrição Experimental. Faculdade de Ciências Farmacêuticas. Universidade de São Paulo. 2008. Disponível em: < http:// www.fcf.usp.br/tabela/>

VAN DEN BERG, H.; FAULKS, R.; GRANADO, H.F.; HIRSCHBERG, J.; OLMEDILLA, B.; SANDMANN, G.; SOUTHON, S.; STAHL, W. The potential for the improvement of carotenoid levels in foods and the likely systemic effects. J. Sci. Food Agricult., v.80, n.7, p.880912, 2000.
ZANUTTO, M. E.; JORDÃO, A. A. Jr.; VANNUCCHI, H. Improvement in vitamin A status with consumption of darkgreen vegetables - a bioavailability study in rabbits. Nutr. Res., v.23, n.3, p.271-278, 2003.

Received for publication on $25^{\text {th }}$ September 2007 Accepted for publication on $7^{\text {th }}$ May 2009 